\title{
Association analysis between the OPG g.27667T $>$ A genetic variant and bone mineral density in Chinese postmenopausal women
}

\author{
J.J. Zhao, D.H. Feng, L. Cheng, T. Lu and L. Wang \\ Department of Orthopedics, The Wuxi People's Hospital, Wuxi, \\ Jiangsu Province, China \\ Corresponding author: J.J. Zhao \\ E-mail: jijun_zhao@sina.cn
}

Genet. Mol. Res. 13 (3): $7332-7338$ (2014)

Received March 26, 2013

Accepted July 26, 2013

Published March 24, 2014

DOI http://dx.doi.org/10.4238/2014.March.24.16

\begin{abstract}
The purpose of this study was to investigate the association of the g.27667T $>$ A genetic variant in the osteoprotegerin $(\mathrm{OPG})$ gene with bone mineral density (BMD) and osteoporosis. A total of 393 primary osteoporosis subjects and 402 healthy controls were recruited. The BMD of the femoral neck hip, lumbar spine $\left(\mathrm{L}_{2-4}\right)$, and total hip were evaluated by Norland XR-46 dual-energy X-ray absorptiometry. The g.27667T $>$ A genetic variant was genotyped using created restriction site-polymerase chain reaction. Our data indicated significant differences in BMD of the femoral neck hip, lumbar spine $\left(\mathrm{L}_{2-4}\right)$, and total hip among different genotypes. Individuals with the genotype TT had significantly higher BMDs than those of genotypes TA and AA $(\mathrm{P}<0.05)$. Results from this study suggest that the g.27667T $>\mathrm{A}$ genetic variant in the OPG gene is potentially related to $\mathrm{BMD}$ and osteoporosis in Chinese postmenopausal women.
\end{abstract}

Key words: Osteoprotegerin gene; Genetic variants; Osteoporosis; Bone mineral density 
OPG gene associated with osteoporosis

\section{INTRODUCTION}

Osteoporosis is a major health problem, particularly in postmenopausal women. It is characterized by microarchitecture deterioration of bone tissue with a consequent increase in fracture risk and a reduction in bone mineral density (BMD) (Cummings et al., 1985; Riggs and Melton III, 1986; Peck, 1993; Kanis et al., 1994; Geng et al., 2007; Garcia-Unzueta et al., 2008; Li et al., 2012; Woo et al., 2012). Low BMD is a major risk factor for osteoporosis and has high heritability (Nguyen et al., 2000; Lee et al., 2010; Ozbas et al., 2012). Genetic factors play important roles in the pathogenesis of osteoporosis (Albagha and Ralston, 2006; Ferrari, 2008; Cheung et al., 2010; Hosoi, 2010; Ralston, 2010; Feng et al., 2012; Woo et al., 2012; Zhang et al., 2013). Previous studies have indicated several genes associated with BMD and osteoporosis, such as the osteoprotegerin (OPG) gene (Pocock et al., 1987; Hofbauer and Schoppet, 2002; Langdahl et al., 2002; Yamada et al., 2003; Arko et al., 2002, 2005; Vidal et al., 2011; Feng et al., 2012; Hussien et al., 2013; Zhang et al., 2013), the estrogen receptor alpha gene (Kurt et al., 2012), and the vitamin D receptor (VDR) gene (Fang et al., 2005; Jakubowska-Pietkiewicz et al., 2012; Kurt et al., 2012; Li et al., 2012; Hussien et al., 2013; Horst-Sikorska et al., 2013). OPG has been considered one of the most important candidate genes for BMD and osteoporosis among these genes. Several studies demonstrated that common genetic variants of OPG likely contribute to BMD and osteoporosis (Pocock et al., 1987; Hofbauer and Schoppet, 2002; Langdahl et al., 2002; Yamada et al., 2003; Arko et al., 2002, 2005; Vidal et al., 2011; Feng et al., 2012; Zhang et al., 2013). The association of the A163G, T245G, T950C, G1181C, G23276A, C21775T, and T23367C genetic variants of OPG with BMD and osteoporosis has been investigated (Arko et al., 2002; Langdahl et al., 2002; Ohmori et al., 2002; Jorgensen et al., 2004; Zhao et al., 2005; Kim et al., 2007; Ueland et al., 2007; Garcia-Unzueta et al., 2008; Moffett et al., 2008; Lee et al., 2010; Feng et al., 2012; Zhang et al., 2013). However, associations of g.27667T $>$ A genetic variant of OPG with BMD and osteoporosis have not yet been detected. Thus, this study aimed to investigate the g.27667T $>\mathrm{A}$ genetic variant of OPG in Chinese postmenopausal women and evaluate its association with BMD and osteoporosis.

\section{MATERIAL AND METHODS}

\section{Subjects}

In this study, 795 subjects, comprising 393 Chinese postmenopausal women with primary osteoporosis and 402 healthy age-matched postmenopausal women, were recruited from the Wuxi People's Hospital (Wuxi, China). All subjects were of Chinese Han nationality. Subjects with present or past history of diseases known to interfere with bone metabolism were excluded. Informed consent forms were obtained from all subjects, and the study protocol was approved by the Ethics Committee of the Wuxi People's Hospital.

\section{Bone mineral density measurement}

The BMD of the lumbar spine $\left(\mathrm{L}_{2-4}\right)$, femoral neck hip, and total hip were evaluated using Norland XR-46 dual-energy X-ray absorptiometry (Norland Coopersurgical Corp., WI, 
USA). BMD was calculated from bone mineral content $(\mathrm{g})$ and bone area $\left(\mathrm{cm}^{2}\right)$, and expressed as $\mathrm{g} / \mathrm{cm}^{2}$.

\section{Genotyping}

Genomic DNA was isolated from peripheral venous blood using the Qiagen method (Hilden, Germany) and stored at $-80^{\circ} \mathrm{C}$ until analyzed. Polymerase chain reaction (PCR) primers were designed using the Primer Premier 5.0 software (Premier Biosoft International, Palo Alto, CA, USA). Primer sequences, annealing temperature, fragment size, region, and genotype size are shown in Table 1. PCRs were performed on $20-\mu \mathrm{L}$ reaction mixtures containing $50 \mathrm{ng}$ mixed DNA template, $10 \mathrm{pM}$ of each primer, $0.20 \mathrm{mM}$ dNTP, $2.5 \mathrm{mM} \mathrm{MgCl}$, and $0.5 \mathrm{U}$ Taq DNA polymerase (TianGen Biotech Inc.). The PCR protocol was carried out as follows: $95^{\circ} \mathrm{C}$ for $5 \mathrm{~min}$ followed by 32 cycles of $94^{\circ} \mathrm{C}$ for $30 \mathrm{~s}, 59.5^{\circ} \mathrm{C}$ for $30 \mathrm{~s}$, and $72^{\circ} \mathrm{C}$ for $30 \mathrm{~s}$, and a final extension at $72^{\circ} \mathrm{C}$ for $5 \mathrm{~min}$. The g.27667T>A single nucleotide polymorphism (SNP) was genotyped using the created restriction site-PCR (CRS-PCR) method with one of the primers containing a nucleotide mismatch, which enabled the use of restriction enzymes for discriminating sequence variations (Yuan et al., 2012, 2013a,b). Aliquots of 5- $\mu \mathrm{L}$ PCR products were digested with $2 \mathrm{U} \mathrm{TaqI}$ restriction enzymes (MBI Fermentas, St. Leon-Rot, Germany) at $37^{\circ} \mathrm{C}$ for $10 \mathrm{~h}$, and were then separated by electrophoresis and observed under UV light. Approximately $15 \%$ random samples of each genotype were detected by DNA sequencing (ABI3730xl DNA Analyzer, Applied Biosystems, Foster City, CA, USA) in order to verify the accuracy of the CRS-PCR method.

\section{Statistical analyses}

All statistical analyses were performed using the Statistical Package for Social Sciences software (SPSS 15.0; SPSS Inc., Chicago, IL, USA). All data are reported as means \pm standard deviation (SD). The chi-squared $\left(\chi^{2}\right)$ test was used to evaluate Hardy-Weinberg equilibrium (HWE) for genotype distributions in case and control groups. The unpaired Student $t$-test and one-way analysis of variance (ANOVA) were used to assess the quantitative data. Multiple regression analyses were used to investigate associations between variables. $\mathrm{P}<0.05$ was considered to be statistically significant.

\section{RESULTS}

\section{Identification of OPG genetic variants}

We found the g.27667T>A genetic variant through CRS-PCR methods, which was verified by DNA sequencing. Based on the OPG reference sequences (GenBank IDs: NG_012202.1, NM_002546.3, NP_002537.3), sequence analyses indicate that this genetic variant is a non-synonymous mutation in exon 5 at position 27,667 of the OPG gene, which is caused by a $\mathrm{T} \rightarrow \mathrm{A}$ mutation, and results in a threonine (Thr) to serine (Ser) amino acid replacement (p.Thr368Ser). The amplified PCR products of the g.27667T $>$ A variant were digested with the TaqI restriction enzyme, and divided into three genotypes: TT (194 and $19 \mathrm{bp}$ ), TA (213, 194, and $19 \mathrm{bp})$, and AA (213 bp) (Table 1). 
Table 1. Primer sequences and CRS-PCR analysis used for detecting the g.27667T $>$ A SNP in the OPG gene.

\begin{tabular}{|c|c|c|c|c|c|c|c|}
\hline SNPs & Primer sequences & $\begin{array}{c}\text { Annealing } \\
\text { temperature } \\
\left({ }^{\circ} \mathrm{C}\right)\end{array}$ & $\begin{array}{c}\text { PCR } \\
\text { amplification } \\
\text { fragment (bp) }\end{array}$ & Region & $\begin{array}{l}\text { Restriction } \\
\text { enzyme }\end{array}$ & $\begin{array}{l}\text { Genotyping } \\
\text { method }\end{array}$ & $\begin{array}{l}\text { Genotype } \\
\text { (bp) }\end{array}$ \\
\hline g. $27667 \mathrm{~T}>\mathrm{A}$ & $\begin{array}{l}\text { 5'-AGCTGTGAAGGAACCTGATCG-3' } \\
\text { 5'-GAAAGAAAGTGGGAGCAGAAGAC-3' }\end{array}$ & 59.5 & 213 & Exon 5 & $\operatorname{Taq} \mathrm{I}$ & CRS-PCR & $\begin{array}{l}\text { TT: } 194,19 \\
\text { TA: } 213, \\
194,19 \\
\text { AA: } 213\end{array}$ \\
\hline
\end{tabular}

CRS-PCR $=$ created restriction site-polymerase chain reaction; $\mathrm{SNP}=$ single nucleotide polymorphism. Underlined nucleotide marks nucleotide mismatches enabling the use of the selected restriction enzymes for discriminating sequence variations.

\section{Allele and genotype distributions}

Table 2 shows the distribution of alleles and genotypes of the g.27667T $>$ A genetic variant in cases of osteoporosis and healthy controls. We found that the $\mathrm{T}$ allele was predominant in the population studied. The chi-squared $\left(\chi^{2}\right)$ test indicated that the distribution of genotypes was in accordance with HWE for the populations studied $(\mathrm{P}>0.05)$.

Table 2. Genotypic and allelic frequencies of g.27667T $>$ A genetic variants in the subjects studied.

\begin{tabular}{|c|c|c|c|c|c|c|c|}
\hline \multirow[t]{2}{*}{ Groups } & \multicolumn{3}{|c|}{ Genotypic frequencies (\%) } & \multicolumn{2}{|c|}{ Allelic frequencies (\%) } & \multirow[t]{2}{*}{$\chi^{2}$} & \multirow[t]{2}{*}{$\mathrm{P}$} \\
\hline & TT & TA & AA & $\mathrm{T}$ & A & & \\
\hline Case group $(\mathrm{N}=393)$ & $171(43.51)$ & $160(40.71)$ & $62(15.78)$ & $502(63.87)$ & $284(36.13)$ & 5.4624 & 0.0651 \\
\hline Control group $(\mathrm{N}=402)$ & $196(48.76)$ & $170(42.29)$ & $36(8.95)$ & $562(69.90)$ & $242(30.10)$ & 0.0099 & 0.9950 \\
\hline \multirow[t]{2}{*}{ Total $(\mathrm{N}=795)$} & $367(46.16)$ & $330(41.51)$ & $98(12.33)$ & $1064(66.92)$ & $526(33.08)$ & 3.1028 & 0.2112 \\
\hline & \multicolumn{3}{|c|}{$\chi^{2}=8.8032, P=0.0123$} & \multicolumn{2}{|c|}{$\chi^{2}=6.5341, P=0.0106$} & & \\
\hline
\end{tabular}

\section{Association between $O P G$ genetic variants and BMD}

Table 3 shows the age, weight, height, body mass index, femoral neck hip BMD, spine $\mathrm{BMD}$, and total hip BMD in each genotype per group. All data are reported as means \pm SD (BMD values were adjusted by age and weight). We detected significant differences of femoral neck hip BMD, spine BMD, and total hip BMD among different genotypes in the subjects. Individuals with the TT genotype showed significantly higher BMDs compared to those with genotypes TA and AA $(\mathrm{P}<0.05$; Table 3$)$.

Table 3. Characteristics of g. $27667 \mathrm{~T}>\mathrm{A}$ SNP in the total group of subjects.

\begin{tabular}{|c|c|c|c|c|}
\hline Genotype & TT & TA & AA & $\mathrm{P}$ \\
\hline Number (\%) & $367(46.16)$ & $330(41.51)$ & $98(12.33)$ & - \\
\hline Age (years) & $63.5 \pm 7.2$ & $63.7 \pm 7.3$ & $63.9 \pm 6.7$ & 0.456 \\
\hline Weight (kg) & $61.4 \pm 6.2$ & $61.5 \pm 6.4$ & $62.8 \pm 6.5$ & 0.352 \\
\hline Height $(\mathrm{cm})$ & $163 \pm 6.9$ & $164 \pm 6.8$ & $165 \pm 6.6$ & 0.247 \\
\hline BMI & $23.1 \pm 3.12$ & $23.2 \pm 3.25$ & $23.6 \pm 3.39$ & 0.246 \\
\hline Femoral neck hip BMD $\left(\mathrm{g} / \mathrm{cm}^{2}\right)$ & $0.739 \pm 0.105$ & $0.699 \pm 0.121$ & $0.688 \pm 0.118$ & 0.039 \\
\hline Spine BMD (g/cm²) & $0.935 \pm 0.101$ & $0.849 \pm 0.157$ & $0.837 \pm 0.126$ & 0.026 \\
\hline Total hip BMD $\left(\mathrm{g} / \mathrm{cm}^{2}\right)$ & $0.875 \pm 0.113$ & $0.819 \pm 0.109$ & $0.808 \pm 0.208$ & 0.018 \\
\hline
\end{tabular}

$\mathrm{SNP}=$ single-nucleotide polymorphism; $\mathrm{BMI}=$ body mass index; $\mathrm{BMD}=$ bone mineral density; Data are reported as means \pm SD (BMD values adjusted by age and weight). 


\section{DISCUSSION}

The OPG gene is one of the most important candidate genes for BMD and osteoporosis (Pocock et al., 1987; Hofbauer and Schoppet, 2002; Langdahl et al., 2002; Yamada et al., 2003; Arko et al., 2002, 2005; Vidal et al., 2011; Feng et al., 2012; Hussien et al., 2013; Zhang et al., 2013). Osteoporosis is a polygenic disease that results from complex interactions between genetic and environmental factors. Identifying genetic variants of OPG could contribute to mediating the genetic influence of osteoporosis and BMD (Pocock et al., 1987; Hofbauer and Schoppet, 2002; Langdahl et al., 2002; Yamada et al., 2003; Arko et al., 2002, 2005; Vidal et al., 2011; Feng et al., 2012; Hussien et al., 2013; Zhang et al., 2013). In this study, we found one novel SNP (g.27667T $>$ A) using CRS-PCR, which was verified by DNA sequencing methods. Significant associations of this SNP were detected with BMD and osteoporosis in Chinese postmenopausal women. Subjects with the genotype TT had significantly higher BMD than those of genotypes TA and AA $(\mathrm{P}<0.05$; Table 3$)$. These results suggest that the T allele could be an increased risk for BMD and osteoporosis in Chinese postmenopausal women. Several previous studies have reported associations of many SNPs with BMD and osteoporosis, such as A163G, T245G, T950C, G1181C, G23276A, C21775T, and T23367C, which is consistent with our results that genetic variants of OPG may contribute a genetic influence on osteoporosis and BMD (Arko et al., 2002; Langdahl et al., 2002; Ohmori et al., 2002; Jorgensen et al., 2004; Zhao et al., 2005; Kim et al., 2007; Ueland et al., 2007; Garcia-Unzueta et al., 2008; Moffett et al., 2008; Lee et al., 2010; Feng et al., 2012; Zhang et al., 2013). The g.27667T >A SNP might be linked to other known non-synonymous SNPs influencing the function of the OPG protein, such as lysine (Lys)3asparagine (Asn), isoleucine (Ile)184methionine (Met), and Thr154Met, which have all been shown to be significantly associated with the risk of BMD and osteoporosis (Zhao et al., 2005; Feng et al., 2012; Zhang et al., 2013). Results from the present study provide more evidence revealing the role of the OPG gene in osteoporosis. In order to elucidate the underlying molecular mechanisms of this association, further studies analyzing this SNP and other genetic variants spanning the whole OPG region in different and larger populations are necessary.

\section{Conflicts of interest}

The authors declare no conflict of interest.

\section{REFERENCES}

Albagha OM and Ralston SH (2006). Genetics and osteoporosis. Rheum. Dis. Clin. North Am. 32: 659-680.

Arko B, Prezelj J, Komel R, Kocijancic A, et al. (2002). Sequence variations in the osteoprotegerin gene promoter in patients with postmenopausal osteoporosis. J. Clin. Endocrinol. Metab. 87: 4080-4084.

Arko B, Prezelj J, Kocijancic A, Komel R, et al. (2005). Association of the osteoprotegerin gene polymorphisms with bone mineral density in postmenopausal women. Maturitas 51: 270-279.

Cheung CL, Xiao SM and Kung AW (2010). Genetic epidemiology of age-related osteoporosis and its clinical applications. Nat. Rev. Rheumatol. 6: 507-517.

Cummings SR, Kelsey JL, Nevitt MC and O’Dowd KJ (1985). Epidemiology of osteoporosis and osteoporotic fractures. Epidemiol. Rev. 7: 178-208.

Fang Y, van Meurs JB, d'Alesio A, Jhamai M, et al. (2005). Promoter and 3'-untranslated-region haplotypes in the vitamin D receptor gene predispose to osteoporotic fracture: The Rotterdam Study. Am. J. Hum. Genet. 77: 807-823. 
Feng G, Meng L, Wang H, Lu Y, et al. (2012). Single-nucleotide polymorphism of the osteoprotegerin gene and its association with bone mineral density in Chinese postmenopausal women. J. Pediatr. Endocrinol. Metab. 25: 11411144.

Ferrari S (2008). Human genetics of osteoporosis. Best. Pract. Res. Clin. Endocrinol. Metab. 22: 723-735.

Garcia-Unzueta MT, Riancho JA, Zarrabeitia MT, Sanudo C, et al. (2008). Association of the $163 \mathrm{~A} / \mathrm{G}$ and $1181 \mathrm{G} / \mathrm{C}$ osteoprotegerin polymorphism with bone mineral density. Horm. Metab. Res. 40: 219-224.

Geng L, Yao Z, Yang H, Luo J, et al. (2007). Association of CA repeat polymorphism in estrogen receptor beta gene with postmenopausal osteoporosis in Chinese. J. Genet. Genomics 34: 868-876.

Hofbauer LC and Schoppet M (2002). Osteoprotegerin gene polymorphism and the risk of osteoporosis and vascular disease. J. Clin. Endocrinol. Metab. 87: 4078-4079.

Horst-Sikorska W, Dytfeld J, Wawrzyniak A, Marcinkowska M, et al. (2013). Vitamin D receptor gene polymorphisms, bone mineral density and fractures in postmenopausal women with osteoporosis. Mol. Biol. Rep. 40: 383-390.

Hosoi T (2010). Genetic aspects of osteoporosis. J. Bone Miner. Metab. 28: 601-607.

Hussien YM, Shehata A, Karam RA, Alzahrani SS, et al. (2013). Polymorphism in vitamin D receptor and osteoprotegerin genes in Egyptian rheumatoid arthritis patients with and without osteoporosis. Mol. Biol. Rep. 40: 3675-3680.

Jakubowska-Pietkiewicz E, Mlynarski W, Klich I, Fendler W, et al. (2012). Vitamin D receptor gene variability as a factor influencing bone mineral density in pediatric patients. Mol. Biol. Rep. 39: 6243-6250.

Jorgensen HL, Kusk P, Madsen B, Fenger M, et al. (2004). Serum osteoprotegerin (OPG) and the A163G polymorphism in the OPG promoter region are related to peripheral measures of bone mass and fracture odds ratios. J. Bone Miner. Metab. 22: 132-138.

Kanis JA, Melton LJ III, Christiansen C, Johnston CC, et al. (1994). The diagnosis of osteoporosis. J. Bone Miner. Res. 9: 1137-1141.

Kim JG, Kim JH, Kim JY, Ku SY, et al. (2007). Association between osteoprotegerin (OPG), receptor activator of nuclear factor-kappaB (RANK), and RANK ligand (RANKL) gene polymorphisms and circulating OPG, soluble RANKL levels, and bone mineral density in Korean postmenopausal women. Menopause 14: 913-918.

Kurt O, Yilmaz-Aydogan H, Uyar M, Isbir T, et al. (2012). Evaluation of ERalpha and VDR gene polymorphisms in relation to bone mineral density in Turkish postmenopausal women. Mol. Biol. Rep. 39: 6723-6730.

Langdahl BL, Carstens M, Stenkjaer L and Eriksen EF (2002). Polymorphisms in the osteoprotegerin gene are associated with osteoporotic fractures. J. Bone Miner. Res. 17: 1245-1255.

Lee YH, Woo JH, Choi SJ, Ji JD, et al. (2010). Associations between osteoprotegerin polymorphisms and bone mineral density: a meta-analysis. Mol. Biol. Rep. 37: 227-234.

Li Y, Xi B, Li K and Wang C (2012). Association between vitamin D receptor gene polymorphisms and bone mineral density in Chinese women. Mol. Biol. Rep. 39: 5709-5717.

Moffett SP, Oakley JI, Cauley JA, Lui LY, et al. (2008). Osteoprotegerin Lys3Asn polymorphism and the risk of fracture in older women. J. Clin. Endocrinol. Metab. 93: 2002-2008.

Nguyen TV, Blangero J and Eisman JA (2000). Genetic epidemiological approaches to the search for osteoporosis genes. J. Bone Miner. Res. 15: 392-401.

Ohmori H, Makita Y, Funamizu M, Hirooka K, et al. (2002). Linkage and association analyses of the osteoprotegerin gene locus with human osteoporosis. J. Hum. Genet. 47: 400-406.

Ozbas H, Tutgun OS and Ozdamar K (2012). Genetic and environmental factors in human osteoporosis. Mol. Biol. Rep. 39: 11289-11296.

Peck WA (1993). Consensus development conference: diagnosis, prophylaxis, and treatment of osteoporosis. Am. J. Med. 94: 646-650.

Pocock NA, Eisman JA, Hopper JL, Yeates MG, et al. (1987). Genetic determinants of bone mass in adults. A twin study. J. Clin. Invest. 80: 706-710.

Ralston SH (2010). Genetics of osteoporosis. Ann. N Y Acad. Sci. 1192: 181-189.

Riggs BL and Melton LJ III (1986). Involutional osteoporosis. N Engl. J. Med. 314: 1676-1686.

Ueland T, Bollerslev J, Wilson SG, Dick IM, et al. (2007). No associations between OPG gene polymorphisms or serum levels and measures of osteoporosis in elderly Australian women. Bone 40: 175-181.

Vidal C, Formosa R and Xuereb-Anastasi A (2011). Functional polymorphisms within the TNFRSF11B (osteoprotegerin) gene increase the risk for low bone mineral density. J. Mol. Endocrinol. 47: 327-333.

Woo J, Kim Y and Lee C (2012). Heterogeneous genetic associations of nucleotide sequence variants with bone mineral density by gender. Mol. Biol. Rep. 39: 2259-2265.

Yamada Y, Ando F, Niino N and Shimokata H (2003). Association of polymorphisms of the osteoprotegerin gene with bone mineral density in Japanese women but not men. Mol. Genet. Metab. 80: 344-349.

Yuan Z, Li J, Li J, Zhang L, et al. (2012). Investigation on BRCA1 SNPs and its effects on mastitis in Chinese commercial 
cattle. Gene 505: 190-194.

Yuan Z, Li J, Li J, Gao X, et al. (2013a). Effects of DGAT1 gene on meat and carcass fatness quality in Chinese commercial cattle. Mol. Biol. Rep. 40: 1947-1954.

Yuan Z, Li J, Li J, Gao X, et al. (2013b). SNPs identification and its correlation analysis with milk somatic cell score in bovine MBL1 gene. Mol. Biol. Rep. 40: 7-12.

Zhang F, He C, Chen G, Li F, et al. (2013). Association analyses of osteoprotegerin gene polymorphisms with bone mineral density in Chinese postmenopausal women. Med. Oncol. 30: 389.

Zhao HY, Liu JM, Ning G, Zhao YJ, et al. (2005). The influence of Lys3Asn polymorphism in the osteoprotegerin gene on bone mineral density in Chinese postmenopausal women. Osteoporos. Int. 16: 1519-1524. 